\title{
Estimation of the Production Cost of Date Fruits of Cultivar Majhoul (Phoenix dactylifera L.) and Evaluation of the Moroccan Competitiveness towards the Major Exporting Regions in the World
}

\author{
Zineb El Bakouri ${ }^{*}$, Reda Meziani'2, Mouaad Amine Mazri'3, \\ Mustapha Ait Chitt ${ }^{4}$, Rachid Bouamri' ${ }^{5}$, Fatima Jaiti1
}

\begin{abstract}
${ }^{1}$ Faculté des Sciences et Techniques, Université Moulay Ismail, Errachidia, Morocco
${ }^{2}$ Institut National de la Recherche Agronomique, CRRA-Errachidia, UR Systèmes Oasiens, Laboratoire National de Culture des Tissus de Palmier Dattier, Avenue Moulay Ali Chérif, Errachidia, Morocco

${ }^{3}$ Institut National de la Recherche Agronomique, CRRA-Marrakech, UR Agro-Biotechnologie, Laboratoire de Biotechnologie Végétale, Marrakech, Morocco

${ }^{4}$ Domaine El Bassatine, Laboratoire de Biotechnologie, Meknès, Morocco

${ }^{5}$ Ecole Nationale d'Agriculture de Meknès, Department of Plant and environment Protection, Km 10, Rte Haj Kaddour, Meknès, Morocco
\end{abstract}

Email: *elbakouri.zineb@gmail.com

How to cite this paper: El Bakouri, Z., Meziani, R., Mazri, M.A., Chitt, M.A., Bouamri, R. and Jaiti, F. (2021) Estimation of the Production Cost of Date Fruits of Cultivar Majhoul (Phoenix dactylifera L.) and Evaluation of the Moroccan Competitiveness towards the Major Exporting Regions in the World. Agricultural Sciences, 12, 1342-1351. https://doi.org/10.4236/as.2021.1211086

Received: October 16, 2021

Accepted: November 27, 2021

Published: November 30, 2021

Copyright $\odot 2021$ by author(s) and Scientific Research Publishing Inc. This work is licensed under the Creative Commons Attribution International License (CC BY 4.0).

http://creativecommons.org/licenses/by/4.0/ (c) (i) Open Access

\begin{abstract}
The aim of the present study was to estimate the production cost of dates of cv. Majhoul (Phoenix dactylifera L.) as part of the Moroccan strategy to develop the date palm sector, and to compare it to that reported in the main exporting regions. Data were collected through surveys of farmers and farm owners carried out in the "Meski Boudnib" extension zone during 2018 and 2019, as well as from studies performed by some governmental organizations. The surveys were conducted on 30 modern and productive date palm farms, managed in monoculture and equipped with localized irrigation systems. All fixed and variable costs were calculated. It was found, through our calculations, that the subsidies from the Moroccan government reduce the average investment cost of a modern date palm farm by $56 \%$. It was also shown that the production cost of one ton of date fruits of $\mathrm{cv}$. Majhoul in the extension zone "Meski Boudnib" (Morocco) is estimated at about 6060 MAD (US\$ 634.5), out of which $28 \%$ represents the labor cost and $23 \%$ represents mineral and organic fertilization costs. The findings of the present study revealed that the production cost of one ton of cv. Majhoul dates in "Meski Boudnib" is lower than
\end{abstract}


those reported in the Coachella Valley $(20,189 \mathrm{MAD} /$ ton; US\$ 2114) and the Jordan Valley (10,536 MAD/ton; US\$ 1103).

\section{Keywords}

Coachella Valley, Cultivar Majhoul, Date Palm Industry, Jordan Valley, Morocco, Production Cost

\section{Introduction}

Date palm (Phoenix dactylifera L.) is a fruit species that plays important socio-economic and ecological roles in the Middle East and North Africa (MENA) region, and is highly valued throughout the world. In fact, date palm is cultivated in more than 30 different countries, with more than 150 million plants belonging to 5000 cultivars [1] and an annual global production of dates exceeding 8 million tons [2]. In Morocco, date palm contributes to the valorization of marginal and degraded soils, and contributes with up to $60 \%$ of the income of 1 million inhabitants of the arid and semi-arid regions [3]. Besides, date palm generates more than 3 million working days per year [4]. These working days concern the work in the palm groves, the date processing and storage units as well as the date palm by-products recovery units. The date palm fruit (i.e. date) is delicious and highly nutritious. It provides many essential nutrients such as carbohydrates, dietary fibers, minerals and vitamins. In addition, dates have health-promoting properties such as anticancer, antioxidant, antimicrobial, antidiarrheal and anti-inflammatory activities, among others [5].

Majhoul cv. is a Moroccan date palm cultivar also known as Mejhoul, Medjool, Medjehuel, Medjhool, and Mejhul [6]. It is the most famous and most sought after date palm cultivar in the world [7]. In addition, the commercial value of the fruits of $\mathrm{cv}$. Majhoul exceeds those of the other date palm cultivars available on the international market. Majhoul cv. is native to Morocco. It was introduced to California in the 1930s [8], and since then it was considered as the most economically important date palm cultivar [9]. Today, and due to their adaptation to different climatic and environmental conditions, plants of date palm cv. Majhoul can be found in many parts of the world. The Majhoul dates, which are known worldwide for their large size, pleasing taste and high quality, are currently exported by Morocco in very limited quantities. In fact, the production of Majhoul dates has decreased considerably because of the bayoud disease, a very dangerous wilt disease caused by the fungus Fusarium oxysporum $\mathrm{f}$. sp. albedinis and that threatens Majhoul plantations in Morocco [10]. Thus, the current production in Majhoul dates barely satisfies the Moroccan consumers [11].

The worldwide exports of the fruits of $\mathrm{cv}$. Majhoul are around 67,000 tons with an economic growth of $5 \%$ to $10 \%$ per year [12]. Around $25 \%$ of this quan- 
tity is intended for the European market [13]. To date, the international market of cv. Majhoul fruits is dominated by the Israeli and American (Californian) dates [14]. It is worth noting that the international market of cv. Majhoul dates holds a great potential. In fact, due to the 67,000 tons exported, the turnover achieved is around US\$ 469 million. Despite the increasing demand from consumers, the dates of $\mathrm{cv}$. Majhoul represents only $4 \%$ to $5 \%$ of the total date exported [15].

Taking into account the competitive market price of $\mathrm{cv}$. Majhoul dates as well as the large and significant profit margin (90\%) [14], the Moroccan date palm plantation program in the extension zones (new date palm groves that are free of bayoud) consists of planting $67 \%$ of $\mathrm{cv}$. Majhoul plants of the total number of date palm plants to be planted [16]. Thus, by 2028, the additional Moroccan production of the dates of $\mathrm{cv}$. Majhoul is estimated to be 70,000 tons [14].

Bearing in mind the recognized importance of the dates of cv. Majhoul, and due to the absence of an economic study on its production cost in Morocco, the aim of the present investigation was to calculate the production cost of cv. Majhoul dates in Morocco, and to compare it with that of the main exporting regions, to assess its ability to compete in the international market.

\section{Materials and Methods}

\subsection{Data Collection}

All data were collected through surveys of farmers and farm owners carried out during 2018 and 2019, as well as from studies carried out by two governmental organizations: the Office for Agricultural Development of Tafilalet (ORMVATF) and the Department of Development of Oasis Areas (DDZO).

The farmers and farm owners with whom the surveys were conducted are located in the "Meski Boudnib" extension zone $\left(31^{\circ} 56^{\prime} 05.9^{\prime \prime} \mathrm{N} 3^{\circ} 57^{\prime} 31.4^{\prime \prime} \mathrm{W}\right.$, Drâa-Tafilalet region, Morocco). This area was once used for pastoralism, but currently contains hundreds of modern date palm farms over an area of 3400 ha [3]. Thus, more than $90 \%$ of the total extension area established for date palm cultivation since the launch of the Moroccan strategy for the development of date palm sector. The Moroccan date palm extension area is growing continuously and will exceed 20,000 ha by 2030 [17].

Our surveys were carried out on 30 modern and productive date palm farms, managed in monoculture and equipped with localized irrigation systems.

\subsection{Production Cost Calculation}

Variable costs are the operating costs that include the costs of energy, fertilizers and phytosanitary treatments as well as the costs of temporary workers. The fixed costs include the depreciation of equipment and buildings, the acquisition cost of plants, the wage of permanent workers and the cost of land rent in the case of tenant farms. In the extension zones, date palm cultivation is undertaken 
on collective lands granted to investors through rental contracts. The rental price is set at $800 \mathrm{MAD}$ (US\$ 83.76) per ha per year. All the fixed costs related to the acquisition of equipment and plant material are computed with and without subsidy in order to assess the importance of the government incentives.

The costs are presented in Moroccan Dirham (MAD) and US dollars (US\$) per hectare, per date palm plant and per ton of date produced (US\$1 $\simeq 9.55$ MAD). Calculations were made based on an average planting density of 123 plants/ha and an average yield estimated at $70 \mathrm{~kg} /$ plant.

\subsection{Comparison of the Production Cost of Dates of cv. Majhoul with the Main Producing Regions}

Determining and comparing the production costs at the international level constitute the fundamental basis for the assessment of the economic competitiveness of any sector [18]. In this experiment, we aimed to compare the production cost of Majhoul dates between the main producing regions in the world. These regions are the Coachella valley in California, USA [9] and the Jordan Valley in the Middle East [19].

\section{Results and Discussion}

\subsection{Estimation of the Production Cost of Dates of cv. Majhoul}

Table 1 revealed that the production cost of dates of $\mathrm{cv}$. Majhoul is estimated at $50,477 \mathrm{MAD} / \mathrm{ha}$ (US\$ 5285.5/ha). The average cost per a date palm plant is about 410 MAD (US\$ 43), while the cost of production of one ton of cv. Majhoul dates is estimated at 6060 MAD (US\$ 634.55). These results are obtained by analyzing the fixed and variable costs as follows:

\subsubsection{Variable Costs}

The variable costs include all expenses directly related to production operations such as energy costs, all agricultural production factors as well as the costs of temporary workers. Based on our analysis, the variable costs are estimated at $33,734 \mathrm{MAD} / \mathrm{ha}$ (US\$3532.35), the equivalent of $274 \mathrm{MAD} /$ plant (US\$28.7) and of $4050 \mathrm{MAD} /$ ton of date produced (US\$ 424 ). This represents $67 \%$ of the total cost of production of $\mathrm{cv}$. Majhoul dates. These costs are distributed as follows:

\section{Irrigation costs}

The irrigation system used in all the date palm farms surveyed in the present study is the drip irrigation. This irrigation system was chosen since it allows a rational water management and prevents the propagation of the bayoud disease [20].

The variable costs related to drip irrigation mainly concern the maintenance costs of the irrigation system that are estimated at $333 \mathrm{MAD} / \mathrm{ha}$ (US\$ 35), which is the equivalent of $3 \mathrm{MAD} /$ plant (US\$ 0.3 ) and of $40 \mathrm{MAD} /$ ton of date produced (US\$ 4). This represents $1 \%$ of the total production cost.

Energy costs

The energy required both for pumping irrigation water and for the operation 
Table 1. Cost of production of dates of date palm cv. Majhoul.

\begin{tabular}{ccccc}
\hline Component & $\begin{array}{c}\text { Cost } \\
\text { MAD/ha }\end{array}$ & $\begin{array}{c}\text { Cost } \\
\text { MAD/plant }\end{array}$ & $\begin{array}{c}\text { Cost } \\
\text { MAD/ton }\end{array}$ & Percentage \\
\hline Variable costs & $33,734.33$ & 274.26 & 4049.74 & $67 \%$ \\
Energy & 6960.00 & 56.59 & 835.53 & $14 \%$ \\
Irrigation & 333.33 & 2.71 & 40.02 & $1 \%$ \\
Fertilization & $11,685.00$ & 95.00 & 1402.76 & $23 \%$ \\
Phytosanitary treatments & 800.00 & 6.50 & 96.04 & $2 \%$ \\
Temporary workers & 5016.00 & 40.78 & 602.16 & $10 \%$ \\
Extra production costs & 8380.00 & 68.13 & 1006.00 & $17 \%$ \\
Other costs & 500.00 & 4.07 & 60.02 & $1 \%$ \\
Fixed costs & $16,742.94$ & 136.12 & 2009.96 & $32 \%$ \\
Land rent & 800.00 & 6.50 & 96.04 & $2 \%$ \\
Construction & 383.33 & 3.12 & 46.02 & $1 \%$ \\
Equipment & 3632.50 & 29.53 & 436.07 & $7 \%$ \\
Drip irrigation system & 1230.17 & 10.00 & 147.68 & $2 \%$ \\
Permanent workers & 9126.00 & 74.20 & 1095.56 & $18 \%$ \\
In vitro plants & 1570.94 & 12.77 & 188.59 & $3 \%$ \\
Total cost & $50,477.27$ & 410.38 & 6059.70 & $100 \%$ \\
\hline
\end{tabular}

of agricultural equipment has an estimated cost of $6960 \mathrm{MAD} /$ ha (US\$ 729), which is the equivalent of $57 \mathrm{MAD} /$ plant (US\$ 6) and $835 \mathrm{MAD} /$ ton of date produced (US\$ 87.5).

\section{Fertilization costs}

The fertilization costs of a modern date palm farm cover the mineral and organic fertilizers. These fertilizers are applied to improve the yield and fruit quality and the protection against pests and diseases [21].

The costs of mineral and organic fertilizers are estimated at $11685 \mathrm{MAD} / \mathrm{ha}$ (US\$ 1223.56), which is the equivalent of $95 \mathrm{MAD} /$ plant (US\$ 10) and 1402 $\mathrm{MAD} /$ ton of date produced (US\$147). This represents $23 \%$ of the total production cost, and showed that fertilization is the most expensive cultural practice in the production process of dates of date palm cv. Majhoul.

\section{Phytosanitary treatment costs}

The costs of phytosanitary treatments cover the costs of purchasing fungicides, insecticides and herbicides. According to our analysis, these costs are estimated at $800 \mathrm{MAD} / \mathrm{ha}$ (US\$ 84), which is the equivalent of $6.5 \mathrm{DH} /$ plant (US\$ 0.7 ) and $96 \mathrm{DH} /$ ton of date produced (US\$ 10 ). This represents only $2 \%$ of the total production cost.

Temporary worker costs

In date palm cultivation, temporary workers are widely hired to support the 
permanent ones in carrying out seasonal agricultural practices that require several working days. These agricultural practices are pruning, fertilization, pollination, thinning, bunch protection and harvesting. It is worth noting that cv. Majhoul. is a very demanding cultivar in terms of labor.

The cost of temporary workers is estimated at $5016 \mathrm{MAD} / \mathrm{ha}$ (US\$ 525.2), which is the equivalent of $41 \mathrm{MAD} /$ plant (US\$ 4.3) and $602 \mathrm{MAD} /$ ton of date produced (US\$ 63). This represents $10 \%$ of the total production cost. Harvesting is the major agricultural practice since it represents $38 \%$ of the temporary worker costs.

\section{Extra production costs}

These costs include the bags used to protect fruit bunches from monsoon rains and the ropes used to fix them [22]. The cost of these products is estimated at $8380 \mathrm{MAD} / \mathrm{ha}$ (US\$ 877.5), which is the equivalent of $68 \mathrm{MAD} /$ plant (US\$ 7) and $1006 \mathrm{MAD} /$ ton of date produced (US\$105.3). This represents $17 \%$ of the total production cost.

\subsubsection{Fixed Costs}

The fixed costs include the cost of land rent, the depreciation of equipment and buildings (construction, equipment and installation of the drip irrigation system), acquisition and planting of date palm plants as well as the wage and social costs of permanent workers. The fixed costs are estimated at $16742 \mathrm{MAD} / \mathrm{ha}$ (US\$ 1753), which corresponds to $136 \mathrm{MAD} /$ plant (US\$ 14.2) and 2010 $\mathrm{MAD} /$ ton date produced (US\$210.5). The fixed costs represent $33 \%$ of the total production cost.

Our analysis showed that the cost of permanent workers is the largest expense, with $18 \%$ of the total production cost, followed by depreciation costs which represent $10 \%$ of the total production cost. The cost of land rent represents only $2 \%$ of the total production cost, while that of plant acquisition and plantation does not exceed $3 \%$ of the total production cost.

\subsection{Effects of the Government Incentives on the Production Cost of Dates of cv. Majhoul}

In Morocco, date palm cultivation has benefited from government support within the framework of the agricultural development fund. The government subsidy supports the acquisition of agricultural equipment, installation of the drip irrigation system as well as the acquisition of in vitro plants. Table 2 shows the effect of the government subsidy on the components of the overall investment.

The findings of the present study showed that the government subsidies reduced the total investment by $56 \%$. Our findings revealed also that installing the drip irrigation system is the most expensive operation, with $42 \%$ of the total investment cost. However, the government subsidy covers $80 \%$ of this cost. The acquisition of date palm plants represents around $1 / 3$ of the total investment

cost, out of which $71 \%$ is covered by the government subsidy (Table 2). The 
Table 2. Effects of the government incentives on the production cost of dates of cv. Majhoul.

\begin{tabular}{cccccccc}
\hline Component & $\begin{array}{c}\text { Cost without } \\
\text { subsidy (MAD) }\end{array}$ & Percentage & $\begin{array}{c}\text { Investment } \\
\text { cost (MAD) }\end{array}$ & Percentage & $\begin{array}{c}\text { Amortized value } \\
\text { with subsidy } \\
\text { (MAD/year /ha) }\end{array}$ & $\begin{array}{c}\text { Amortized value } \\
\text { without subsidy } \\
\text { (MAD/year /ha) }\end{array}$ \\
variation \\
Construction & $337,400.00$ & $9 \%$ & $337,400.00$ & $20 \%$ & 383.33 & 383.33 & $0 \%$ \\
Equipment & $834,000.00$ & $22 \%$ & $709,000.00$ & $42 \%$ & 3632.50 & 4170.00 & $13 \%$ \\
Drip irrigation system & $1,594,000.00$ & $42 \%$ & $318,800.00$ & $19 \%$ & 1230.17 & 6150.83 & $80 \%$ \\
In vitro plants & $1,033,200.00$ & $27 \%$ & $333,200.00$ & $20 \%$ & 1136.00 & 3936.00 & $71 \%$ \\
Total & $3,838,600.00$ & $100 \%$ & $1,698,400.00$ & $100 \%$ & 6582.00 & $14,840.17$ & 0.56 \\
\hline
\end{tabular}

agricultural equipment represents $22 \%$ of the total investment cost, out of which $13 \%$ is covered by the government subsidy. Building construction is the least expense, thus representing only $9 \%$ of the total investment. This item does not benefit from subsidy.

\subsection{Comparison of the Production Cost of Dates of cv. Majhoul with the Main Producing Regions}

The findings of the present work showed that, in the "Meski Boudnib" extension zone in Morocco, the production cost of one ton of dates of cv. Majhoul is estimated at 6060 MAD (US\$ 634.5). This cost is relatively low when compared to the production costs reported in the main producing regions of the dates of cv. Majhoul. Indeed, the production cost of one ton of dates of cv. Majhoul in the Jordan valley was estimated at 10,536 MAD (US\$1103.2) [23], while it was estimated at 20,189 MAD (US\$2114) in the Coachella valley [24].

Three main factors can explain this difference in costs: 1) the temporary workers hired in California for the production of dates of cv. Majhoul cost almost ten times higher than the temporary workers in the extension zone of Morocco. In the Jordan valley, the temporary worker cost is almost the double of that estimated in Morocco [25]. 2) The cost of acquiring and planting date palm plants in Morocco (in vitro plants obtained through organogenesis) constitutes only $50 \%$ and $25 \%$ of the costs reported in the Jordan valley and the Coachella valley, respectively. It is worth noting that, in USA, date palm is propagated through offshoots due to the absence of the bayoud disease. 3) In Morocco, the cost of land rent represents only $2 \%$ of the total production cost of cv. Majhoul dates, while it represents $14 \%$ in the Jordan valley [26] and 20\% in the Coachella valley [24]. Besides, our analysis revealed that the cost of land in the Coachella valley and the Jordan valley is 56 and 13 times higher than that of the "Meski Boudnib" extension zone, respectively [26].

\section{Conclusion}

The findings of the present investigation showed that the production of dates of cv. Majhoul in Morocco can be highly competitive in the international market. 
This is due to several factors such as government subsidies, the low costs of permanent and temporary workers as well as the very low land rent cost. More studies will be carried out to evaluate the impact of other factors such as climate change on the production cost of dates of cv. Majhoul in Morocco, in order to assess the competitiveness of the Moroccan Majhoul dates in the international market under different potential scenarios.

\section{Conflicts of Interest}

The authors declare no conflicts of interest regarding the publication of this paper.

\section{References}

[1] Sedra, M.H. (2013) Guide du phoeniciculteur: Mise en place et conduite des vergers phoénicicoles. INRA, Rabat.

[2] FAOSTAT (2017) Agro-Statistics. Database. Food and Agriculture Organization of the United Nations, Rome.

[3] MAPMDREF (2019)

https://www.agriculture.gov.ma/fr/filiere/palmier-dattier

[4] ANDZOA (2018) Rapport d'activité 2017. Direction de Développement des Zones Oasiennes. $92 \mathrm{p}$.

[5] Bouhlali, E.D.T., Bammou, M., Sellam, K., Benlyas, M., Alem, C. and Filali-Zegzouti, Y. (2016) Evaluation of Antioxidant, Antihemolytic and Antibacterial Potential of Six Moroccan Date Fruit (Phoenix dactylifera L.) Varieties. Journal of King Saud University-Science, 28, 136-142. https://doi.org/10.1016/j.jksus.2016.01.002

[6] Mazri, M.A., Meziani, R., El Fadile, J. and Ezzinbi, A. (2016) Optimization of Medium Composition for in Vitro Shoot Proliferation and Growth of Date Palm cv. Mejhoul. 3 Biotech, 6, Article No. 111. https://doi.org/10.1007/s13205-016-0430-x

[7] Sedra, M.H. (2015) Date Palm Status and Perspective in Morocco. In: AlKhayri, J.M., Jain, S.M. and Johnson, D.V., Eds., Date Palm Genetic Resources and Utilization, Springer, Dordrecht, 257-323. https://doi.org/10.1007/978-94-017-9694-1 8

[8] Dawson, C. (2017) La datte au Maroc. FruiTrop, No. 247, 20-25.

[9] Krueger, R. (2015) Date Palm Status and Perspective in the United States. In: AlKhayri, J.M., Jain, S.M. and Johnson, D.V., Eds., Date Palm Genetic Resources and Utilization, Springer, Dordrecht, 447-485.

https://doi.org/10.1007/978-94-017-9694-1 14

[10] Mazri, M.A., Meziani, R., Belkoura, I., Mokhless, B. and Nour, S. (2018) A Combined Pathway of Organogenesis and Somatic Embryogenesis for an Efficient Large-Scale Propagation in Date Palm (Phoenix dactylifera L.) cv. Mejhoul. 3 Biotech, 8, Article No. 215. https://doi.org/10.1007/s13205-018-1235-x

[11] Belguedj, M. (2010) Préservation des espèces oasiennes et stratégie à mettre en œuvre. Cas du palmier dattier (Phoenix dactylifera L.) Institut Technique de Développement Agricole Saharienne. ITDAS/OADA.

[12] Libsker, A. (2020) Black Gold: How One Variety of Dates Took Over a Billion Shekels Industry. https://www.freshplaza.com

[13] CBI (2020) The European Market Potential for Dates.

https://www.cbi.eu/market-information/processed-fruit-vegetables-edible-nuts/date 
s/market-potential

[14] MAPMDREF (2015) Directives stratégique pour la filière phoenicicole. http://www.agriculture.gov.ma

[15] Meziani, R. (2019) Mise au point d'un schéma de micropropagation optimal par organogenèse du palmier dattier (Phoenix dactylifera L.) cv. Majhoul. Thèse de Doctorat, Université Moulay Ismail, Faculté des sciences et technique d'Errachidia, Meknes.

[16] Meziani, R., Jaiti F., Mazri, M.A., Anjarne, M., Ait Chitt, M., El Fadile J. and Alem, C. (2015) Effects of Plant Growth Regulators and Light Intensity on the Micropropagationof Date Palm (Phoenix dactylifera L.) cv. Mejhoul. Journal of Crop Science and Biotechnology, 18, 325-331. https://doi.org/10.1007/s12892-015-0062-4

[17] ANDZOA (2017) Réalisation de l'etude de suivi des investissements agricoles, et elaboration du plan parcellaire et de la vision de developpement de la zone des extensions agricoles, axe meski-boudnib, province d'errachidia. $71 \mathrm{p}$.

[18] Lachaal, L. (2001) La compétitivité: Concepts, définitions et application. Options Méditerranéennes, 57, 29-36.

[19] Abu-Qaoud, H. (2015) Date Palm Status and Perspective in Palestine. In: Al-Khayri, J., Jain, S. and Johnson, D., Eds., Date Palm Genetic Resources and Utilization, Springer, Dordrech, 423-439. https://doi.org/10.1007/978-94-017-9707-8 13

[20] Sedra, M.H. (2003) Le palmier dattier base de la mise en valeur des oasis au Maroc, techniques phoénicicoles et création d'oasis. INRA, $265 \mathrm{p}$.

[21] Berger, F. and Gayrard, M. (2018) Raisonner la fertilisation en pratiquant des apports fractionnés ou localisés. EcophytoPIC.

http://ecophytopic.fr/prevenir/fertilisation-raisonnee

[22] Sedra, M.H. (2011) Development of New Moroccan Selected Date Palm Varieties Resistant to Bayoud and of Good Fruit Quality. In: Jain, S.M., Al-Khayri, J.M. and Johnson, D.V., Eds., Date Palm Biotechnology, Springer, Dordrecht, 513-531. https://doi.org/10.1007/978-94-007-1318-5 24

[23] Ibrahim, A.A., Haddad, A. and Chouiki, T.C. (2018) Date Palm Cultivation and Production of Dates in Jordan. 189 p.

[24] Takele, E., Mauk, P. and Sharabeen, I. (2007) Sample Costs to Establish a Date Palm Orchard and Produce Dates in the Coachellavalley, Riverside County, 2005-2006. University of California Cooperative Extension (UCCE), Humboldt County, CA.

[25] Altarawneh, M. and Altahat, E. (2013) Econometric Analysis of Medjool Date Production Costs in Jordan. Scientific Journal of King Faisal University (Basic and Applied Sciences), 14, 49-68.

[26] Jordan Investment Commission (2017) Etude de faisabilité économique de projet de palmier dattier Majhoul. $50 \mathrm{p}$. 


\section{Abbreviations}

$\begin{array}{ll}\text { MAD } & \text { Moroccain Dirham } \\ \text { US\$ } & \text { United States Dollars } \\ \text { MENA } & \text { Middle East and North Africa }\end{array}$

MAPMDREF Ministère de l'Agricuture, de la Pêche Maritime, du Développement Rural et des Eaux et Forêts

ANDZOA Agence National pour le Développement des zones oasiennes et de l'Arganier

$\mathrm{Cv} \quad$ cultivar

CBI Centre for the Promotion of Imports from developing countries

ITC International Trade Center

DDZO Department of Development of Oasis Areas

ORMVATF Office for Agricultural Development of Tafilalet 